\title{
CHARACTERISTICS OF THE TOPOGRAPHY AND GEOLOGY OF VUNG MAY SEA MOUNTAIN AREA, TRUONG SA, VIETNAM
}

\author{
Phi Truong Thanh ${ }^{1 *}$, Duong Quoc Hung ${ }^{2}$, Nguyen Van Diep ${ }^{2}$, Le Dinh Nam² \\ ${ }^{1}$ Hanoi University of Natural Resources and Environment \\ ${ }^{2}$ Instutute of Marine Geology and Geophysics, VAST \\ *E-mail: thanhgislab@gmail.com
}

Received: 3-8-3017

\begin{abstract}
Using the REFLEXW software, Ver. 6.0, analysis and processing of high resolution shallow seismic data of 13 cross section profiles in the Vung May sea mountain area, the analytical results have divided the boundaries of the reflected layers on the top surface and slope of sea mountain at each cross section, corresponding to the boundary of the sediment layers based on the stratigraphy and the results of previous studies in the study area and adjacent areas. In addition, the analytical results also determined the depth values and coordinate of the seabed surface on each section, as the basis to build the 3D model of sea mountain surface and draw the topographic cross sections to calculate the slope angle at each position on the surface around the sea mountain. Based on the geomorphological characteristics and slope angle, the sea mountain surface is divided into three parts: Top surface, slope surface and foot surface. Each part of the sea mountain has separate geological and geomorphological features. At the top surface, the topography has lagoon-shaped form, surrounded by elevated edge. The size of the lagoon is about $45 \mathrm{~km}$ long, $20 \mathrm{~km}$ wide, 10 $40 \mathrm{~m}$ deep and slope angle is smaller than 0.5 degrees $\left(<0.5^{\circ}\right)$. On the slope surface, topography is divided into two parts: The first one lies at a depth from the upper flank to $-750 \mathrm{~m}$ deep, slope angle is within $8-20^{\circ}$; the second one lies at a depth from $-750 \mathrm{~m}$ to $-1,400 \div-1,500 \mathrm{~m}$, slope angle is smaller, varies in the range of $4-10^{\circ}$. At the foot of sea mountain, the terrain is a large area, at the depth of $-1,400 \div-1,500 \mathrm{~m}$ with slope angle within $1-5^{\circ}$. The results obtained in this study are consistent with previous studies in the area and adjacent areas.
\end{abstract}

Keywords: High resolution seismic profile, cross sections, coral, topography, slope angle.

\section{INTRODUCTION}

The Truong Sa archipelago is located in the Eastern Vietnam Sea, belongs to the Khanh Hoa Province and is an integral part of the Vietnamese territory, has strategic position of economic aspects, politics and defense security. The Truong Sa archipelago consists of coral reefs, sand dunes and coral reefs with hundreds of square meters. The area of the islands in the Truong $\mathrm{Sa}$ archipelago is very small, no more than $5 \mathrm{~km}^{2}$. The average height of the islands ranges from $2.5 \mathrm{~m}$ to $3.5 \mathrm{~m}$, especially the height of Song Tu Tay island is $6.0 \mathrm{~m} \mathrm{[1]}$. The surface area of the islands in the area of the Truong Sa archipelago depends on the season and the meteorological and regional conditions of the area. The slope angle of these islands varies within $20-30^{\circ}$ [2].

The studies in the Truong $\mathrm{Sa}$ archipelago area have been conducted since the 16th century by Western navigators and the Truong Sa archipelago was named by the Royal Navy in 1843. It is also an international name commonly used to refer to the Truong $\mathrm{Sa}$ 
archipelagos of Vietnam. Since 1922, the French began to exploit the Truong $\mathrm{Sa}$ and Hoang $\mathrm{Sa}$ archipelago. The most typical geological study of the islands and continental shelf of Vietnam is based on the results of the initial survey on the topography, geomorphology and seabed sediments, is E. Saurin (1950-1960).

Since the late 1960s, a series of foreign petroleum companies from Russia, USA, Australia, Germany, France, Italy, UK, Malaysia... conducted geological and geophysical surveys in the Sea, including the Truong Sa islands and Tu Chinh - Vung May sea mountain. In particular, there was geological and geophysical study in the Sea, including the Truong Sa archipelago from the Far East Center, the Russian Academy of Sciences. After this period, the geological features and tectonic structure of the Truong Sa archipelago and Tu Chinh - Vung May have been mentioned in other studies by [3-5],...

In Vietnam, the Truong Sa archipelago and Tu Chinh - Vung May has been studied for a long time, under Le-Trinh Kingdoom $\left(16^{\text {th }}\right.$ and $17^{\text {th }}$ centuries) and the real researches in this area have just started after 1975. And to serve the goal of developing sea-island economy and protecting territorial waters, surveys in this area began to be carried out continuously from 1993 to present on the islands and sea mountains of the Truong Sa archipelago through State-level research projects belonging to the East Sea Truong Sa program. A series of structural tectonic studies at this stage is published, typically they are the studies of [6-18],...

In this issue, the studies of $[7,8,19]$ have described in detail the terrain and geomorphologic features and material components... in the islands belonging to the Truong Sa archipelago; [1] have analyzed in detail the geological and terrain features of Song Tu Tay, Truong Sa, Nam Yet and Son Ca islands in the Truong Sa archipelago; [20] have used a geophysical method to analyze the geophysical features of the crust to determine the layer surfaces of the Earth's crust, fault systems and sedimentary formations of Truong Sa archipelago area.
Later, [21] used geological data, collected in April 1998, to analyze the chemical composition of the samples in Phan Vinh sea mountain area, Da Tay and has indicated that coral reefs with a major origin have biological sedimentary, relatively monotonic carbonate composition; [22] gave an overview of development trends of coral reef in the Truong $\mathrm{Sa}$ archipelago. However, most of the above studies have not yet quantified the geomorphological characteristics of each island and sea mountain in the Truong Sa archipelago area.

In this paper, using the high resolution shallow seismic data collected in 2003 from the project: "The survey of geology, geophysics and meteorology in the Southwest of Truong Sa archipelago and adjacent continental shelf" performed by $\mathrm{Vu}$ Nang Pham and using REFLEXW software, Ver. 6.0 together with some other specialized softwares, the authors will clarify the topographic and morphological characteristics of Vung May sea mountain within the region $7^{\circ} 26^{\prime} 35.31^{\prime \prime}-8^{\circ} 8^{\prime} 1.2^{\prime}$ 'N, $111^{\circ} 15^{\prime} 50.23^{\prime}$ - $111^{\circ} 48^{\prime}$ (fig. 1).

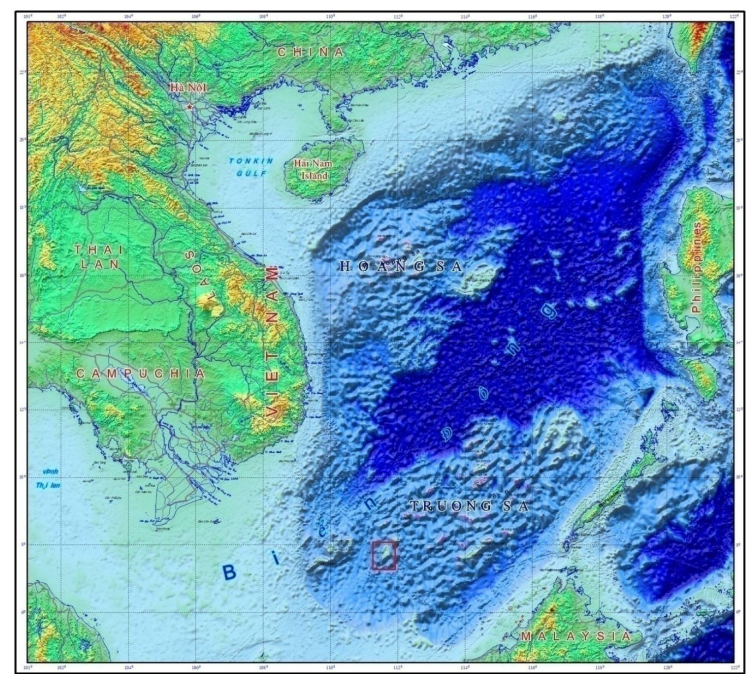

Fig. 1. Map of study location

\section{MATERIAL AND METHODS}

\section{Material}

The data used to analyse topological and morphological characteristics of Vung May sea mountain area in three dimensional space (3D) 
are high resolution shallow seismic data of 13 lines with total length of $461.14 \mathrm{~km}$ which are collected from GEONT equipment, Sparker resource, made in Russia, through the project: "The survey of geology, geophysics and meteorology in the Southwest of Truong Sa archipelago and adjacent continental shelf', performed by Vu Nang Pham (2003). The location of the high resolution shallow seismic survey lines is shown in fig. 2.

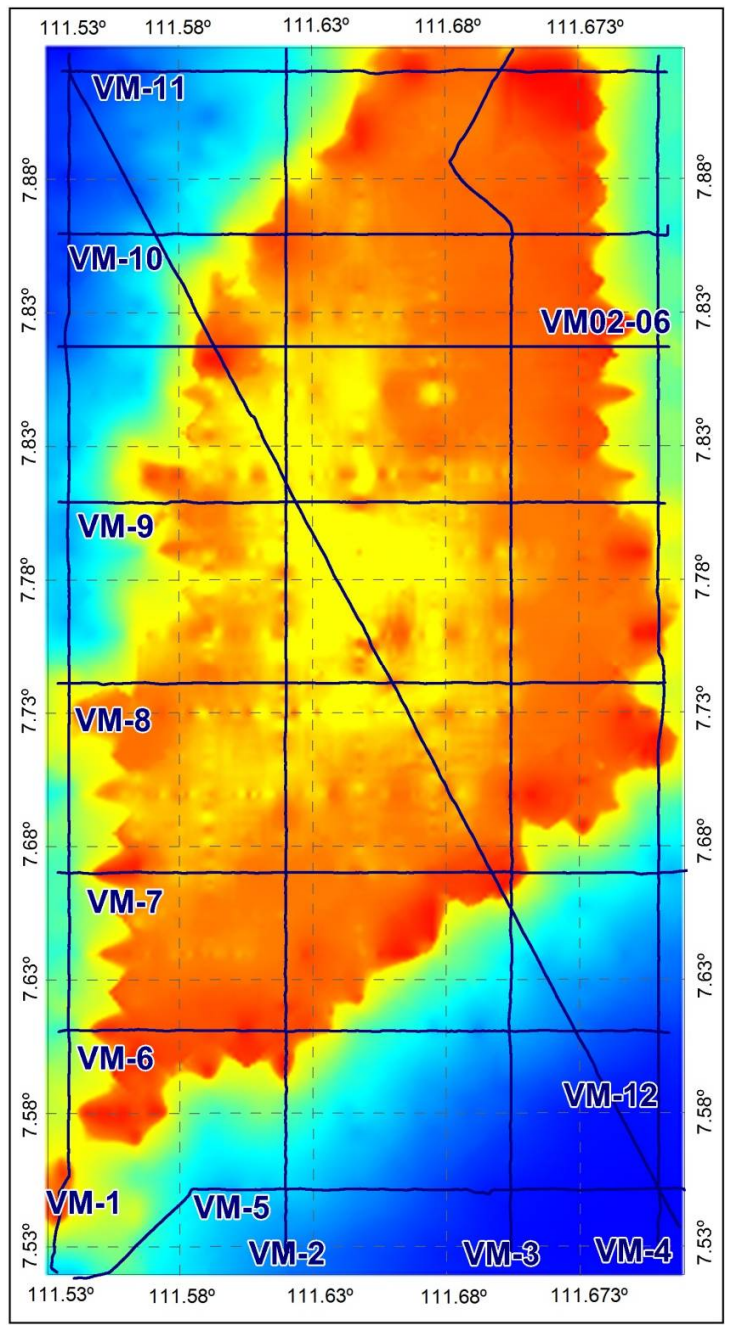

Fig. 2. Map of the high resolution shallow seismic survey lines in Vung May sea mountain area

\section{Methods}

The method used in this paper include: Mapping method - GIS and seismic- stratigraphic method. In particular, the GIS method is used to draw maps, determine study locations and other information on the map; the seismic stratigraphic method is used to analyse and process seismic data through REFLEXW software, Ver. 6.0, including the below steps:

Step 1: The seismic data collected from the Sparker sources are converted and formatted to process using REFLEXW software, Ver. 6.0, including: Signal filtering, deconvolution and stacking to get the high quality of seismic profiles, reflecting clear boundaries and seismological characteristics.

Step 2: Using the seismic-stratigraphic method, the boundary of the seismic sequences is divided based on the contrast in intensity and frequency; continuity and stability of synchronous axes... are the base to connect stratigraphy of the adjacent areas.

Step 3: Building the seismic - geological cross sections; seabed terrain; reflected surfaces and the thickness of the sedimentary layer in three dimensional space (3D). Besides, the analyses of the angle of the topographic surface are also determined by using software which is programmed from the Visual Basic language Ver. 6.0 and other modules.

\section{ANALYTICAL RESULTS}

\section{Topographic and geomorphologic characteristics}

The analysis and building of the topographic surface of the Vung May sea mountain area in 3D are conducted on 12 high resolution shallow seismic lines in fig. 2 and are presented in fig. 3 .

These profiles are then located according to their positions and represented in 3D as shown in fig. 4.

By using the REFLEXW software, Ver. 6.0, high resolution shallow seismic profiles are processed and filtered to separate the reflecting layers, corresponding to the boundary of the sedimentation sequences and determine the depth values of topographic surface on the each section. The depth value is expressed by the 
points $\mathrm{X}, \mathrm{Y}, \mathrm{Z}$, corresponding to the value of each depth and coordinates (latitude longitude). These depth values are then interpolated using Surfer software, Ver. 12.0 and represented in 3D as in fig. 5.
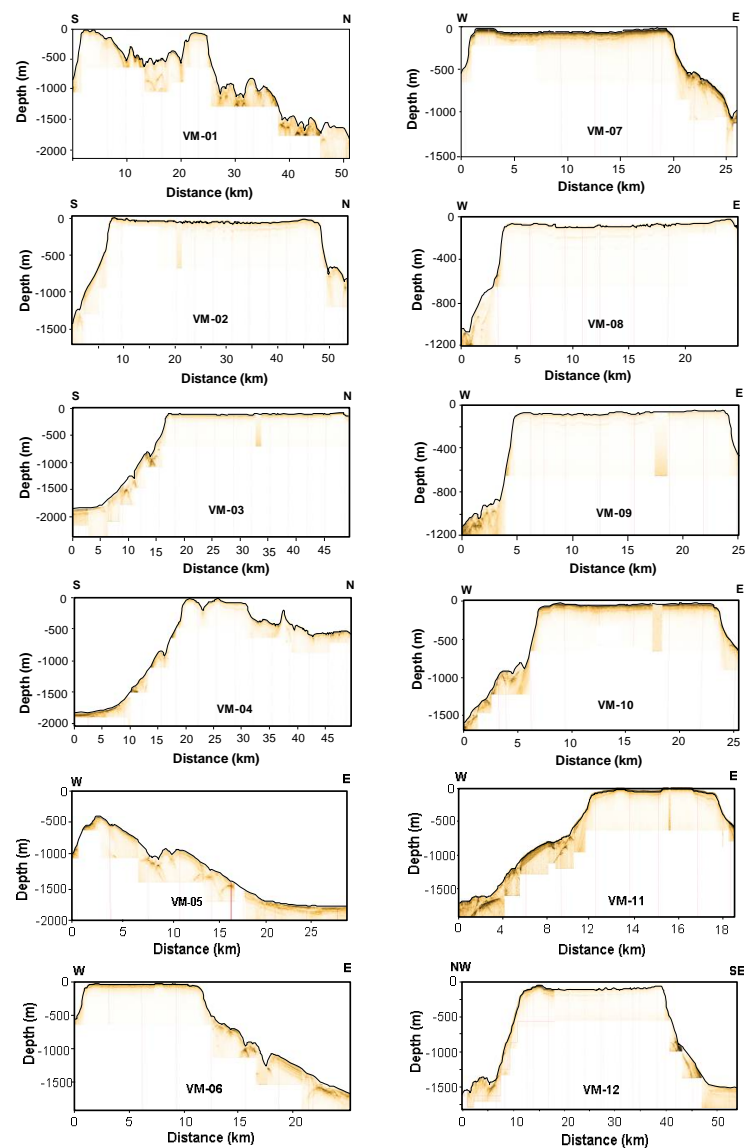

Fig. 3. High resolution shallow seismic profiles of Vung May mountain area

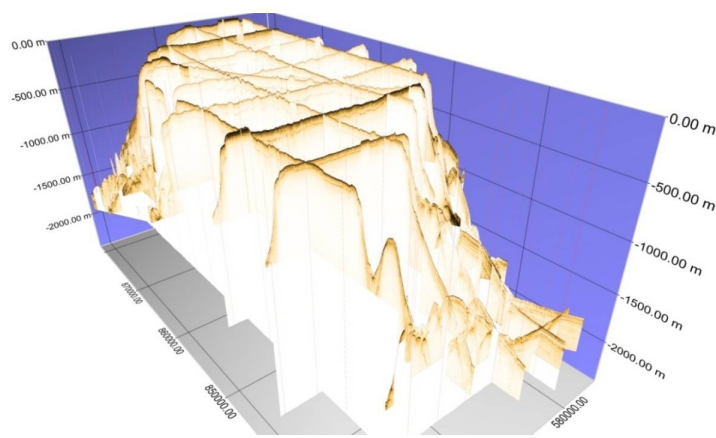

Fig. 4. Location of high resolution shallow seismic profiles in Vung May sea mountain area in 3D

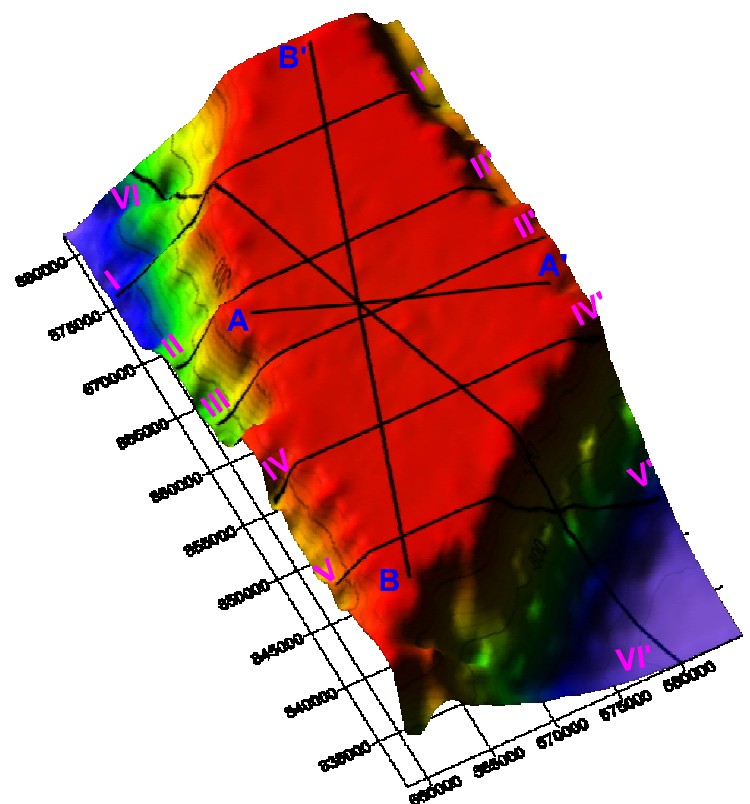

Fig. 5. Three-dimensional (3D) model of terrain surface and cross section lines in the Vung May mountain area

The surface of Vung May sea mountain area after plotting in 3D has the elliptical form in north-south direction, within coordinates of $7^{\circ} 26^{\prime} 35.31^{\prime \prime} \quad-8^{\circ} 8{ }^{\prime} 1.2^{\prime \prime} \mathrm{N}, 111^{\circ} 15^{\prime} 50.23^{\prime}$ ' $111^{\circ} 48^{\prime} \mathrm{E}$ with $50-53 \mathrm{~km}$ long, $20-25 \mathrm{~km}$ wide.

To analyse geomorphologic and topographic characteristics in Vung May sea mountain area, the topographic cross section lines are designed as in fig. 6.

The topographic cross section lines in fig. 6 are plotted in fig. 7 .

The analytical results of each cross section in Vung May sea mountain area determine that the top surface is relatively flat; the slope surface around the sea mountain has the slope angle varying from $5^{\circ}$ to $20^{\circ}$, at the depth from $5-6 \mathrm{~m}$ to $-1,900 \div-2,000 \mathrm{~m}$. Based on the topographic differentiation of the digital model and on the cross-sections, the topographic surface of the Vung May sea mountain and adjacent area is divided into three separate parts: Top surface, slope surface and foot surface. 
The top surface: Is quite flat, surrounded by the edge, forming lagoons with slope angle smaller than $5^{\circ}\left(<0.5^{\circ}\right)$. In the center of the sea mountain, lagoon is about $45 \mathrm{~km}$ long and $20 \mathrm{~km}$ wide, 10 - $40 \mathrm{~km}$ deep (fig. 8).

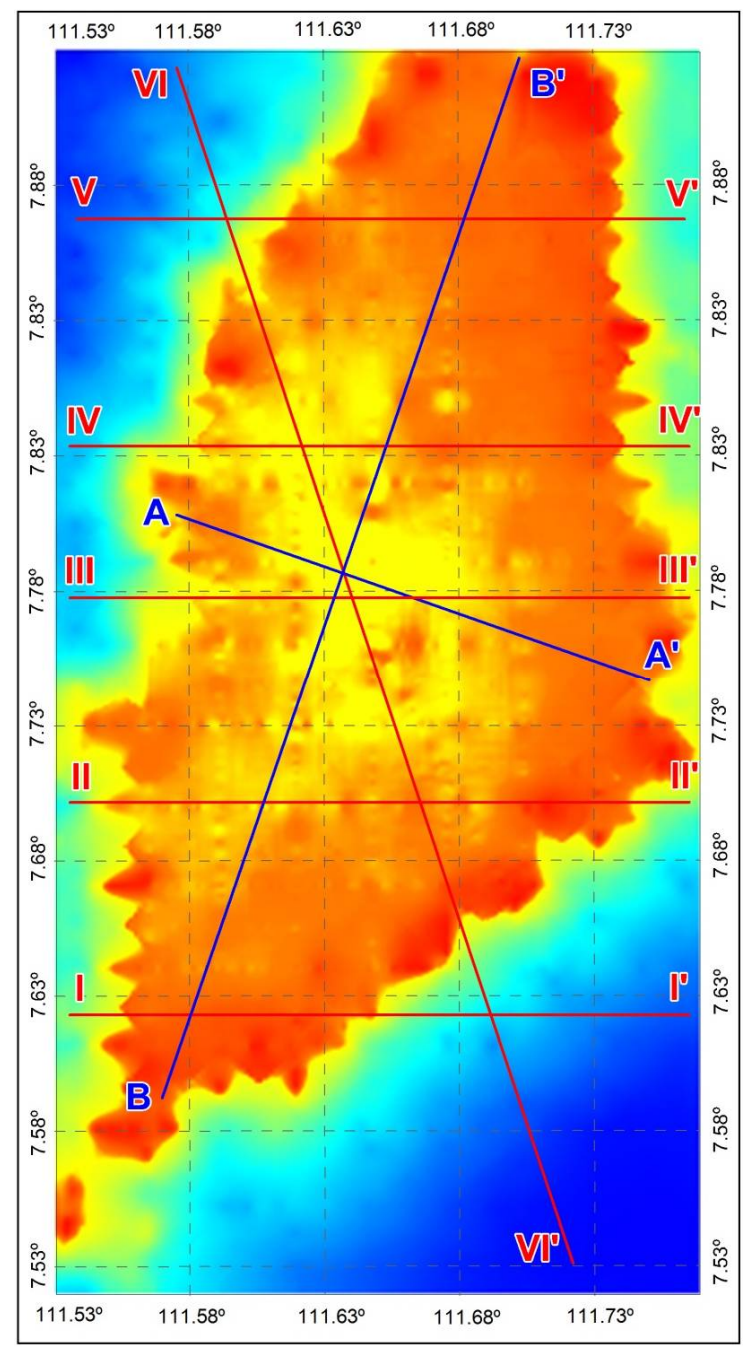

Fig. 6. Topography of the Vung May sea mountain area interpolated from the high resolution shallow seismic data

At the edge, their structure is complex. The elevation between the edge and the center of the lagoon is about $40-50 \mathrm{~m}$. The edge is below the current water level from $1-2 \mathrm{~m}$ to $10-20 \mathrm{~m}$. The edge terrain is not flat with thousands of meters of difference (fig. 9). According to the degree of closure of the edge, this type is open loop atoll (fig. 9).
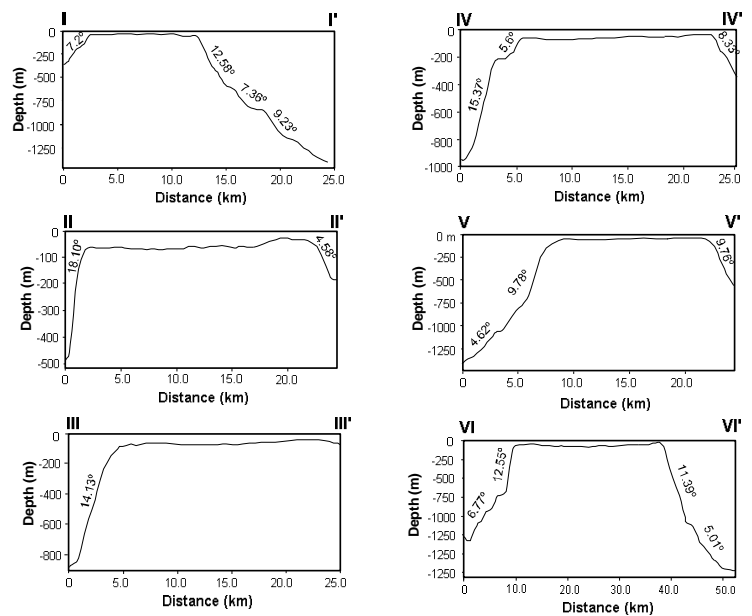

Fig. 7. Topographic cross sections of Vung May sea mountain area
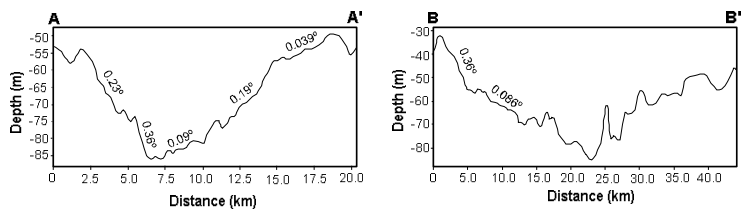

Fig. 8. Cross sections A-A' and B-B' in the directions of NW-SE and NE-SW through the Vung May sea mountain center

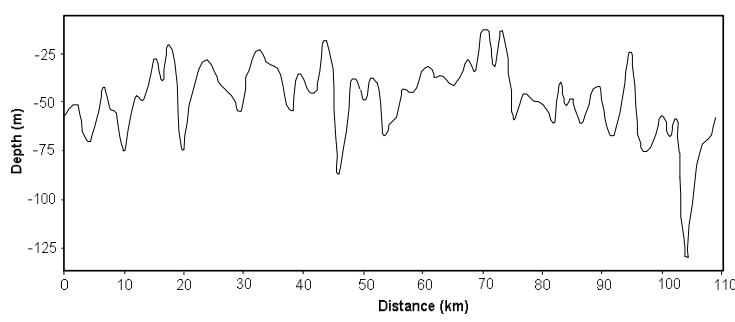

Fig. 9. Cross-section of the topography around the Vung May sea mountain area

Sea mountain slope: The analytical results of the digital topographic, the high resolution shallow seismic profiles and topography cross sections in fig. 3, 7 and 8 show that the surface of sea mountain slope has wavy form, running from the top surface to the foot of sea mountain. The geomorphology of this sea mountain is quite even around.

Based on slope angle, the terrain surface can be divided into two parts: The first one is in the depth from the top surface to $-750 \mathrm{~m}$, with the slope angle within $8-20^{\circ}$; the second one is 


\section{Characteristics of the topography and geology...}

in the depth from $-750 \mathrm{~m}$ to $-1,500 \mathrm{~m}$, with the slope angle within $4-10^{\circ}$ (fig. 7 ).

The foot of sea mountain: Is a large area, surrounded at the depth of $-1,400 \mathrm{~m}$ to deeper. It is seen on the high resolution shallow seismic profiles, being cut in the W-E direction. The angle of foot surface area is within $1-5^{\circ}$.

\section{Geological characteristics}

The Truong Sa archipelago belongs to the transition zone between the continental and oceanic crust. Their basement structure is cut strongly, forming graben and half graben, deposited by Cenozoic sediments. The characteristics of the sediment of this area are determined on the basis of seismic data, sea bottom geological samples and deep-sea drilling samples. [21] and the other authors suggested that the geological characteristics of the islands belonging to the Truong $\mathrm{Sa}$ archipelago have the same coral origin.

The atolls and coral reefs in the Truong Sa archipelago are formed on positive geological structures with large size. At the top of these structures, lighting conditions are sufficient temperature and salinity of seawater are consistent with coral growth. The basic part of positive structures can have magnetic origin or eruptions. The results of exploratory drilling in the islands such as Song Tu Tay and large Truong Sa islands showed that at the depth of $30 \mathrm{~m}$, there are solid coral reefs with the component of $\mathrm{CaCO}_{3}$. The result of the interpretation of the stratigraphic seismic profiles of Vung May sea mountain area determined the different sedimentary layers on the top surface, slope based on analyzing seismic data.

\section{The top surface area}

On the seismic profile VM02-06 (fig. 10), the sedimentary layers on the top surface are located at the center of the lagoon and in the depression between the high blocks along the edge zone, reflecting clearly sedimentary layers from the top to the bottom. Based on comparing the previous studies in the area [2, $8,14,17,21-23]$, the geological characteristics of each layer are presented as follows:
The first layer is defined as a complex structure, consisting of sand, coral reefs mudflats, boulders, pebbles and coral gravels, with loose structure to weak bonds. The layer thickness varies from $7-8 \mathrm{~m}$ at the edge of the lagoon and around the overhanging blocks to $15-16 \mathrm{~m}$ in the middle of the lagoon.

The comparative results of borehole data on the islands and the sea mountain in the Truong Sa archipelago determined that this sedimentary layer was formed during the Holocene-present period (from 11 - 12 thousand years to now).

The second layer is characterized by blank waves, identified as sand, gravel which was formed by the weathering process, due to the destruction of the frame of coral, during the late Pleistocene regression. This layer has a thickness which varies strongly, mainly in the range of $10-20 \mathrm{~m}$.

The third layer is characterized by a subclass wave with horizontal synchronous reflections or bend with average amplitude. This layer consists of the sandwiched layers of mud and coral reefs of various shapes and sizes, formed due to the destruction of coral reef rock formations at the coastal zones and the blocks, under the influence of sea waves. The layer is 15 - $25 \mathrm{~m}$ thick and predicted as early-mid Pleistocene.

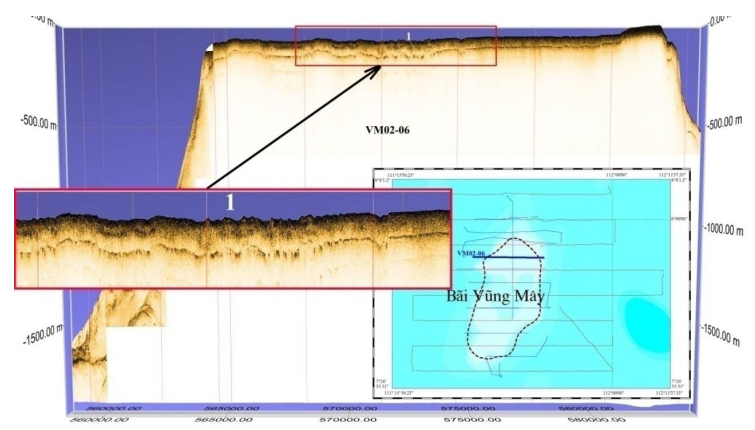

Fig. 10. Characteristics of sedimentary layers on the top surface of high resolution shallow seismic profile VM02-06 in the north of Vung May sea mountain area

The slope of the sea mountain

Similarly, in the lower slope part of cross- 
section VM02-06, seismic waves do not clearly indicate the sedimentary layers, reflecting the complexity of the geological structure. The sedimentary layer thickness varies from 20 to $200-300 \mathrm{~m}$ in the lower slope and $700-800 \mathrm{~m}$ at the foot of sea mountain (fig. 11).

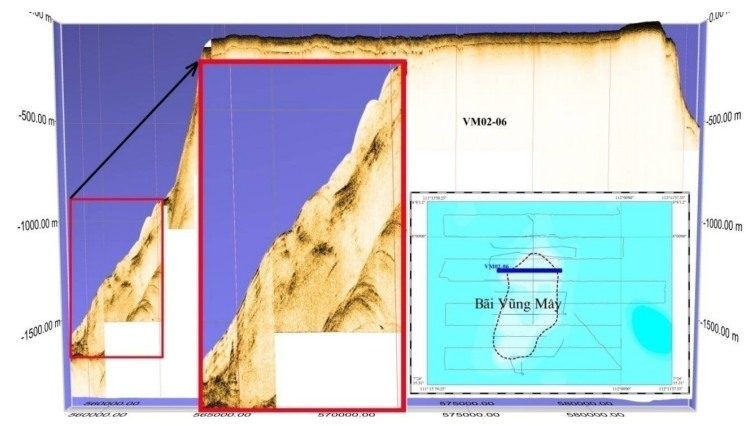

Fig. 11. Sedimentary layer in the lower part of the slope on the high resolution shallow section

VM02-06, in the north of Vung May sea mountain area

Similar to the top surface, the sedimentary formations on the slope can also be divided into the following three layers:

The first layer is characterized by the blank wave, relatively homogeneous at the top, gradually changed to the layered form with the phases from medium to strong at the lower part of sea mountain and it has the thickness increasing toward the depth of slope, from 20 $30 \mathrm{~m}$ at the upper part to $40-50 \mathrm{~m}$ at the lower part. The wave field of this layer reflects the heterogeneity of the geological structure on the slope area. The analytical results compared to the adjacent area showed that this layer consists of sand, weakly bonded coral reefs, intercalated with the thin clay layers, changing along the slope area.

The second layer is characterized by the tilted axis of the wave, bend, discontinuity and amplitude decrease according to the depth of the slope. The thickness of this layer varies from $15 \mathrm{~m}$ to $20 \mathrm{~m}$ at the top, increases to 40 $50 \mathrm{~m}$ at the bottom. Similar to the first one, the second wave field also reflects the geological heterogeneity of structure across the entire layer. The geological formations are defined as clayey mud, with significant thickness, intercalated with sand, gravel and coral reefs.

The third layer lies on the top of the coral massif with a uniform structure, having a thickness of about $150 \mathrm{~m}$, consisting mainly of moderate to solid coral sandstone formations. In the lower part of the slope, the occurrence of uniform reflection waves can be observed with, strong amplitude, bending, showing the presence of thin clay layers, coral boulders and branches.

\section{The foot of sea mountain}

The seismic waves are the uniform axes, parallel to each other, reflecting clearly structural layers. On the seismic profile VM0206 , through the deep water 1,950 - 2,000 $\mathrm{m}$ in the north of Vung May sea mountain area, the sedimentary layers are $600-700 \mathrm{~m}$ in thickness, structured in five layers, formed during the transgression period of PlioceneQuaternary. The supply of sedimentary material was determined to be from the top surface and the slope surface area. The analysis results on the other high resolution shallow seismic sections in Vung May sea mountain area were also in the same as the seismic profile VM02-06.

According to Pham Nang Vu (2003), the Vung May sea mountain area and other islands in the Truong $\mathrm{Sa}$ archipelago area are formed by the coral masses. In the Vung May sea mountain, the rock masses are about 500 $600 \mathrm{~m}$ in height, formed on the high land of older rocks in the period of Oligocene - Late Miocene and developed continuously from late Miocene to present, through 3 main stages:

The stage 1: The coral mass is built at the top of ancient rock blocks, in the transgression stage (Late Miocene - Early Pliocene) at the depth of $450-500 \mathrm{~m}$.

The stage 2: The coral mass is expanded during the regression in the Late PlioceneQuaternary and the sediment is deposited at the foot of sea mountain area.

The stage 3: The top part is coral mass, having the thickness of about $400-500 \mathrm{~m}$, with 
steep slope and no sedimentary formations are covered.

The monolithic coral masses are surrounded by sedimentary layers with $20 \mathrm{~m}$ in thickness, many holes, karst, formed by coral rock of many generations, sometimes filled by mud and broken coral. On the high resolution shallow seismic profiles, the top layer is characterized by uniform wave axis, bent, tiled, superimposed with amplitude from medium to weak. The coral rock mass is solid and homogeneous, characterized by blank wave.

\section{CONCLUSIONS}

The analytical results from the high resolution shallow seismic data of 13 crosssections in Vung May sea mountain area within the coordinates $\left(7^{\circ} 26^{\prime} 35.31^{\prime},-8^{\circ} 8^{\prime} 1.2^{\prime}{ }^{\prime} \mathrm{N}\right.$, $\left.111^{\circ} 15^{\prime} 50.23^{\prime \prime} \quad-111^{\circ} 48^{\prime} \mathrm{E}\right)$ using the REFLEXW software, Ver. 6.0 have determined the boundary of reflective surfaces of seabed and sedimentary sequences. The values of seabed on each high resolution shallow seismic profile are obtained, including: Coordinates (longitude and latitude) and depth, being a base for creating three dimensional model, drawing the topographic cross section and calculating the slope angle.

Based on the calculated program of slope angle on the seabed surface, programmed from Visual Basic 6.0 language and other modules, the slope angle of the seabed surface reflects clearly the difference among top surface, slope and foot of sea mountain. In particular, at the top surface the topography has lagoon-shaped form, and is surrounded by elevated edge with about $45 \mathrm{~km}$ long, $20 \mathrm{~km}$ wide, 10 - $40 \mathrm{~m}$ deep and slope angle is smaller than 0.5 degree $\left(<0.5^{\circ}\right)$; at the slope surface, topography is divided into two parts: The first one lies at a depth from the upper flank to the $-750 \mathrm{~m}$ deep, slope angle is within $8-20^{\circ}$; the second one lies at a depth of $-750 \mathrm{~m}$ to $-1,400 \div-1,500 \mathrm{~m}$, slope angle is smaller, varies in the range of 4 $10^{\circ}$; at the foot surface, the terrain is in large size, at the depth $-1,400 \div-1,500 \mathrm{~m}$ with slope angle within $1-5^{\circ}$. The results obtained in this study are consistent with some previous studies in the adjacent area. However, this is only a research result in the vast area of the Truong $\mathrm{Sa}$ archipelago.

In order to carry out the strategy of political economy and defense-security, the study in detail and quantitative characteristics of geology and geomorphology on the island and sea mountain in the Truong $\mathrm{Sa}$ archipelago should be further promoted in many research programs.

\section{REFERENCES}

1. Nguyen The Tiep, 1996. Geomorphological and geological features of the Truong Sa archipelago. Contributions of marine geology and geophysics, Vol. II. Science and Technics Publishing House, Hanoi. Pp. 146-155.

2. Bui Thi Bao Anh, Do Huy Cuong, Nguyen Duc Thanh, Nguyen Thi Nhan, 2014. The geoengineering basis for the construction of buildings on the islands and under sea level plains belonging to Truong Sa archipelago. Journal of Marine Science and Technology, 12(4A), 171-178.

3. Holloway, N. H., 1982. North Palawan block, Philippines-Its relation to Asian mainland and role in evolution of South China Sea. AAPG Bulletin, 66(9), 13551383.

4. Hinz, K., and Schlüter, H. U., 1985. Geology of the Dangerous Grounds, South China Sea (Vietnam East Sea), and the continental margin off southwest Palawan: results of SONNE Cruises SO-23 and SO27. Energy, 10(3-4), 297-315.

5. Hinz, K., and Schlüter, H. U., 1985. Geology of the Dangerous Grounds, South China Sea (Vietnam East Sea), and the continental margin off southwest Palawan: results of SONNE Cruises SO-23 and SO27. Energy, 10(3-4), 297-315.

6. Do Tuyet, 1978. Some features of geomorphology in the Truong Sa archipelago. Journal of Geology, (136), 16-19.

7. Nguyen Bieu, 1985. Some features of geology in the Truong Sa archipelago. Journal of Geology, (169). 
8. Tran Van Hoang, 1996. The problem of protection for geological environment in the rise islands belonging to Truong $\mathrm{Sa}$ archipelagos. Contributions of marine geology and geophysics, Vol VII. Science and Technics Publishing House. Pp. 169-171.

9. Bui Cong Que et al., 1998. Some features of the Earth's crust structure in the Truong $\mathrm{Sa}$ archipelago area according to geophysical data. Contributions of Marine Geology and Geophysics. Publishing House for Science and Technology. Pp. 115-126.

10. Le Duc An, 1998. Some characteristics of seabed geomorphology in the Truong Sa archipelago and adjacent area. Contributions of natural condition and natural resources of the Truong $\mathrm{Sa}$ archipelago. Publishing House for Science and Technology. Pp. 37-42.

11. Le Duc An, 1999. General data on the geomorphology of coral plateaus in the Hoang $\mathrm{Sa}$ and Truong $\mathrm{Sa}$ archipelagos. Vienam Journal of Earth Sciences, 21(2), 153-160.

12. Bo Nguyen Quang, Nguyen Du Hung, Tran Quan Hoan, Nguyen Van Dac, Tran Duc Chinh, 1998. Tu Chinh Bank area in structural plan of Southeast Vietnam continental shelf. PetroVietnam ReviewMay.

13. Nguyen The Tiep, 1998. Characteristics of geomorphology and geology in the Truong $\mathrm{Sa}$ archipelago area. Contributions of natural condition and natural resources of the Truong Sa archipelago. Publishing House for Science and Technology. Pp. 26-36.

14. Tran Duc Thanh, 1998. Some chacteristics of geology in the Truong Sa archipelago. Contributions of natural condition and natural resources of the Truong $\mathrm{Sa}$ archipelago. Publishing House for Science and Technology. Pp. 93-103.

15. Nguyen Nhu Trung et al., 2002. Characteristics of deep structure in the Truong Sa archipelago area according to satellite gravity data. Vienam Journal of Earth Sciences, 24(2), 348-361.
16. Nguyen Van Luong, Le Tram, Le Quoc Hung, 2002. Terrain and geological structure around the Spratly Islands according to high resolution shallow seismic data and Echo sound data. Vienam Journal of Earth Sciences, 24, 146-154.

17. Nguyen Tu Dan et al., 2006. Geomorphology of coral formations in the Truong Sa archipelago. Vietnam Academy of Science and Technology, (6), 92-101.

18. Le Dinh Nam et al., 2013. The principle geomorphological characteristics of Spratly islands and Tu Chinh-Vung May areas. The second national scientific conference on marine geology, Hanoi - Ha long, 10-12 October. Publishing House for Science and Technology. Pp. 207-218.

19. Nguyen Van Bach et al., 1998. Some characteristics of topography geomorphology and sediments of shallow water in the Truong Sa sea. Journal of Geology, (247).

20. Bui Cong Que, Nguyen Van Giap, Nguyen Thu Huong, Le Tram, Nguyen Duc Thanh, Do Huy Cuong, Tran Tuan Dung, 1996. Some characteristics of the Earth's crust structure of the Truong Sa region based on the geophysical data. Contributions of marine geology and geophysics, Vol. II. Science and Technics Publishing House, Hanoi. Pp. 13-22.

21. Ngo Van Quang, Pham Quoc Hiep, 2003. The principal geological and petrochemical characteristics of the reef-forming rocks of the top section of some islands in Truong Sa (Spratly) archipelago. Contributions of marine geology and geophysics, Vol. VII. Science and Technics Publishing House. Pp. 87-97.

22. Nguyen Tien Hai, Nguyen Van Bach, Nguyen Huy Phuc, Nguyen Trung Thanh, 2003. Tendency of development and changeable hidden of atolls in the Truong Sa island region. Contributions of marine geology and geophysics, Vol. VII. Science and Technics Publishing House. Pp. 285-292.

23. Duong Quoc Hung, Thanh Nhi Bui, Nguyen Kim Thanh, Nguyen Van Diep, 
Characteristics of the topography and geology...

2012. The shallow geological characteristics of Truong Sa Island water submerged area according to high resolution seismic data. Contributions of marine geology and geophysics, Vol XII. Science and Technics Publishing House. Pp. 115-121. 